\title{
Jaw-opening oromandibular dystonia secondary to Wilson's Disease treated with botulinum toxin type $A$
}

\author{
Distonia oromandibular com abertura da boca secundária à doença de Wilson tratada \\ com toxina botulínica tipo A
}

Hélio A.G. Teive', Leandro E. Klüppel², Renato P. Munhoz¹, Nílson Becker', Paulo R. Müller², Lineu C. Werneck

\begin{abstract}
We have reported a case series of five patients with jaw-opening oromandibular dystonia secondary to Wilson's disease (WD), in which the patients were treated with botulinum toxin type A (BTX-A). In all cases, dystonia score was partially reduced three weeks after injections. The most common side effect was transient mild dysphagia. This preliminary study showed that jaw-opening oromandibular dystonia in WD may be partially responsive to the use of BTX-A.
\end{abstract}

Key words: Wilson's disease, focal dystonia, oromandibular dystonia.

\section{RESUMO}

Relata-se uma série de cinco casos de distonia oromandibular com abertura da boca, secundária à doença de Wilson, em que os pacientes foram tratados com toxina botulínica tipo A. Em todos os casos, a distonia oromandibular com abertura da boca foi parcialmente reduzida três semanas após as injeções. 0 efeito adverso mais comum foi a disfagia leve e transitória. Este estudo preliminar mostrou melhora parcial da distonia oromandibular com abertura da boca.

Palavras-Chave: doença de Wilson, distonia focal, distonia oromandibular.

Wilson's disease (WD), or hepatolenticular degeneration, is a rare autosomal recessive inherited disease of cupper metabolism, which presents with hepatic, psychiatric, and neurological symptoms ${ }^{1-6}$. The prevalence rate of $\mathrm{WD}$ is estimated to be one case per $30,000^{1-6}$. WD is caused by mutations to the gene coding for ATPase copper transporting beta polypeptide (ATP7B), which is located on chromosome 13, allowing the incorporation of copper into ceruloplasmin and its subsequent excretion into the bile $e^{1,25-9}$. Neurologic signs include Parkinsonism, dysarthria, tremor, dystonia (particularly craniofacial and oromandibular), and cerebellar abnormalities. The safest and most efficient form of pharmacological therapy remains a matter of debate and includes the use of D-penicillamine and zinc ${ }^{1-6}$. Generally, treatment improves most neurological symptoms and signs to a variable degree. However, dystonic forms, particularly, oromandibular dystonia (OMD), with jaw-opening, are particularly resistant to the treatment ${ }^{1-6}$. The objective of our study was to evaluate the effects of botulinum toxin type A (BTX-A) injections for the treatment of jaw-opening OMD in patients with WD.

\section{CASES}

We included five patients (three men and 2 women, mean age 27.2 years-old) with a genetically confirmed diagnosis of WD and neurological involvement. Mean follow-up was 8.6 years-old (Table). All cases presented disabling jaw-opening OMD (three patients had a worsening of OMD after use of dpenicillamine), refractory to other forms of clinical interventions, including anticolinergics (biperiden), baclofen, clonazepam, and tetrabenazine. BTX-A (Botox, Allergan, USA) was injected according to the following protocol: 35 units for each lateral pterygoid muscle (electromyography-guided intra-

\footnotetext{
'Movement Disorders Unit, Neurology Service, Internal Medicine Department, Hospital de Clínicas, Federal University of Paraná, Curitiba PR, Brazil; 2Department of Oral and Maxillofacial Surgery, Federal University of Paraná, Curitiba PR, Brazil. 
Table. Jaw-opening oromandibular dystonia secondary to Wilson's disease: demographics and botulinum toxin efficacy.

\begin{tabular}{|c|c|c|c|c|c|c|}
\hline Patient & Age (years) & Gender (M:F) & Follow-up (years) & $\begin{array}{c}\text { BFM Scale (Mouth) } \\
\text { pre-BTX-A }\end{array}$ & $\begin{array}{l}\text { BFM Scale (Mouth) } \\
\text { post-BTX-A }\end{array}$ & $\begin{array}{l}\text { Side effects: } \\
\text { dysphagia }\end{array}$ \\
\hline 1 & 32 & $\mathrm{~F}$ & 12 & 8 & 6 & Mild \\
\hline 2 & 30 & M & 13 & 8 & 6 & Mild \\
\hline 3 & 36 & M & 7 & 6 & 4.5 & Mild \\
\hline 4 & 25 & $\mathrm{~F}$ & 5 & 4.5 & 3 & - \\
\hline 5 & 23 & M & 6 & 2 & 1.5 & - \\
\hline Mean & 27.2 & $3: 2$ & 8.6 & 5.7 & 4.2 & Mild \\
\hline
\end{tabular}

M: male; F: female; BFM: Burke-Fahn-Marsden; BTX-A: botulinum toxin type A.

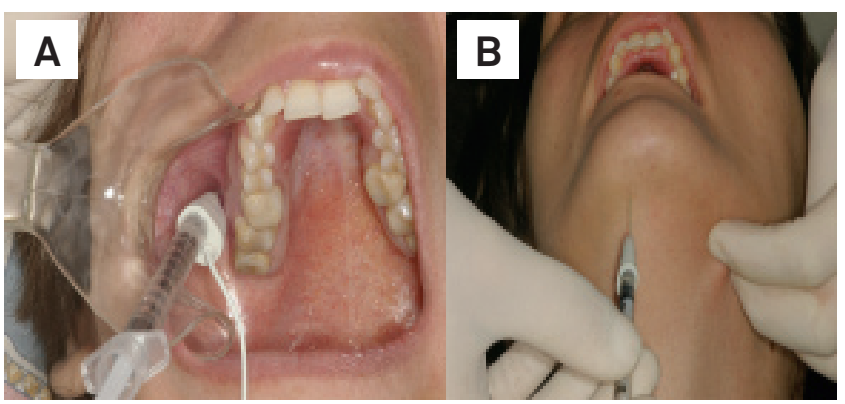

Fig 1. Botulinum toxin injection. (A) lateral pterygoid muscle; (B) submentalis muscle complex.

oral injection); 30 units for the submentalis complex (total amount of BTX-A=100 units), as seen in Fig 1. Patients were assessed at baseline (when injections were performed), after three weeks and three months using the sub-item "Mouth" of the Burke-Fahn-Marsden Scale (BFMS=0-8 points) ${ }^{10}$.

The scores for jaw-opening OMD were partially improved after using BTX-A in all cases, ranging from mean value of 5.7 (pre-BTX-A) to 4.2 points (post-BTX-A), as shown in Table and illustrated in Fig 2. Specific informed consent from the patient, for publication of all figures, was obtained. The most common side effect was mild transient dysphagia in three cases.

\section{DISCUSSION}

In the classical description of Samuel Kinnier Wilson on the progressive lenticular degeneration, different phenotypes were described, such as the dystonic (including a tremulous form) and Parkinsonian forms ${ }^{11}$.

Since then, several additional clinical variants of neurological WD were documented, including the seminal David Marsden's manuscript, which classified WD into three clinical neurological forms: hyperkinetic form, with dystonic syndrome; ataxic form, with postural and intentional tremor associated with cerebellar ataxia; and a Parkinsonian form ${ }^{3}$.

In a Brazilian series of 119 patients with WD published by Machado et al., the authors found that $69 \%$ of the patients had dystonia ${ }^{12}$. Dystonia in patients with WD is frequently focal, including blepharospasm, cervical dystonia, dystonic dysphonia,

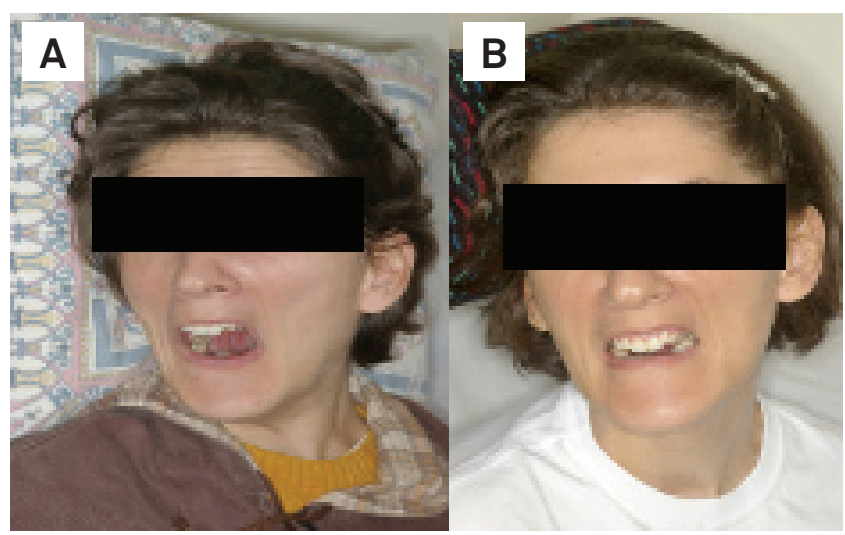

Fig 2. Patient 1 - jaw-opening oromandibular dystonia. (A) prebotulinum toxin injection; (B) post-botulinum toxin injection.

lingual dystonia, writer's cramp, and OMD. Segmental and generalized dystonia are less frequent in $\mathrm{WD}^{6,13}$.

$\mathrm{OMD}$ is a rare focal form of dystonia, characterized by repetitive involuntary jaw movements, subdivided in jawopening or jaw-closing types. Symptoms may interfere with essential daily living activities, such as feeding, chewing, swallowing, and speaking ${ }^{14-16}$. This form of dystonia is often associated with blepharospasm (defining Meige's syndrome), and cervical dystonia (referred to as cranial-cervical dystonia). Jaw-closing OMD is caused by dystonic spasms of the masseter and temporalis muscles, leading to trismus and bruxism. Jaw-opening OMD is caused by dystonic contractions of lateral pterygoids, anterior belly of the digastric muscle, and submentual muscles ${ }^{13}$.

Treatment of WD patients with OMD, particularly jaw-opening OMD, represents a challenging matter, which includes controversial opinions. Additionally, its occurrence has been linked to certain genotypes among the more than 400 mutations already described in the ATP7B gene ${ }^{1,17-19}$, and to iatrogenic worsening of neurological manifestations, especially dystonia, in WD patients treated with d-penicillamine $e^{5,6,20-22}$. In our small series of WD patients with jaw-opening OMD, $60 \%$ had worsening of OMD dystonia after using d-penicillamine.

Pharmacological treatment of OMD includes medications such as anticolinergics (biperiden), tetrabenazine, baclofen and benzodiazepines (clonazepam), but the efficacy 
falls below the acceptable one ${ }^{13}$. In general, BTX-A is an effective treatment option in patients with $\mathrm{OMD}^{14}$. Jaw-closing OMD is improved by toxin botulinum use in $85 \%$ of the patients. Frequently, jaw-opening OMD is less responsive than jaw-closing, and it is more likely to be associated with dysphagia and dysarthria ${ }^{13-16}$.

Jaw-opening OMD, involving the injections of lateral pterygoid muscles, requires the use of electromyography, with needle electrodes, using an intraoral approach ${ }^{16}$, and the use of BTX-A in the submentalis complex can improve the results ${ }^{14-16,23}$. In our series of Brazilian patients with WD and jaw-opening OMD, the use of BTX-A was performed with the participation of colleagues from the Department of Oral and Maxillofacial Surgery, with the objective of improving our results.
To date, there are no published studies about the use of BTX-A in jaw-opening OMD patients with WD. Our preliminary findings showed that BTX-A is partially effective (mild to moderate efficacy) in improving jaw-opening OMD in patients with WD, and the most common side effect was transient mild dysphagia, which occurred in $60 \%$ of our patients.

\section{ACKNOWLEDGMENTS}

The authors thank Professor Luís dos Ramos Machado (Faculdade de Medicina da Universidade de São Paulo FMUSP) for his kind comments on this manuscript.

\section{References}

1. Lorincz MT. Neurologic Wilson's disease. Ann NY Acad Sci 2010;1184:173-187.

2. Pfeiffer RF. Wilson's disease. Semin Neurol 2007;27:123-132.

3. Marsden CD. Wilson's disease. Q J Med 1987;65:959-966.

4. Brewer GJ, Gurkan VY. Wilson's disease. Medicine 1992;71:139-164.

5. Brewer GJ.Wilson's disease: a clinician's guide to recognition, diagnosis, and management. Boston: Kluwer Academic Publishers, 2001.

6. Hoogenraad T. Wilson's disease. London, UK:W. B. Saunders Company Ltd; 1996.

7. Tanzi RE, Petrukhin K, Chernov I, et al. The Wilson disease gene is a copper transporting ATPase with homology to the Menkes's disease gene. Nat Genet 1993;5:344-350.

8. Bull PC, Thomas GR, Cox DW, et al. The Wilson disease gene is a putative cooper transporting P-Type ATPase similar to Menkes gene. Nat Genet 1993;5:327-337.

9. Ferenci P. Regional distribution of mutations of the ATP7B gene in patients with Wilson's disease: impact on genetic testing. Hum Genet 2006;120:151-159.

10. Burke RE, Fahn S, Marsden CD, Bressman SB, Moskowitz C, Friedman J. Validity and reability of a rating scale for the primary torsion dystonias. Neurology 1985;35:73-77.

11. Wilson SAK. Progressive lenticular degeneration: a familial nervous disease associated with cirrhosis of the liver. Brain 1912;34:295.

12. Machado AA, Chien HF, Deguti MM, et al. Neurological manifestations in Wilson's disease: report of 119 cases. Mov Disord 2006;21:2192-2196.

13. Cardoso F, Jankovic J. Oromandibular dystonia. In: Tsui JKC, Calne DB (Eds). Handbook of dystonia. New York, USA: Marcel Dekker, Inc.; 1995.
14. Tan EK, Jankovic J. Botulinum toxin A in patients with oromandibular dystonia: long-term follow-up. Neurology 1999;53:2102-2107.

15. Singer C, Papapetropoulos S. A comparison of jaw-closing and jawopening idiopathic oromandibular dystonia. Parkinsonism Relat Disord 2006;12:115-118.

16. Moller E, Bakke M, Dalager T, Werdelin LM. Oromandibular dystonia involving the lateral pterygoid muscles: four cases with different complexity. Mov Disord 2007;22:785-790.

17. MachadoAA, Deguti MM, GenschelJ, etal. Neurological manifestations and ATP7B mutations in Wilson's disease. Parkinsonism Relat Disord 2008;14:246-249.

18. Deguti MM, Genschel J, Cançado EL, et al. Wilson's disease: novel mutations in the ATP7B gene and clinical correlation in Brazilian patients. Hum Mutat 2004;23:398.

19. de Bem RS, Muzzillo DA, Deguti MM, Barbosa ER, Werneck LC, Teive HAG. Wilson's disease in southern Brazil: a 40-year follow-up study. Clinics 2011;66:411-416.

20. Walshe JM. Wilson's Disease. New Oral Therapy. Lancet 1956; 270:25-26.

21. Barbosa ER, Scaff M, Canelas HM. Hepatolenticular degeneration: evaluation of neurological course in 76 treated patients. Arq Neuropsiquiatr 1991;49:399-404.

22. Narata AP, Troiano AR, Teive HAG, Werneck LC. Doença de Wilson: manifestação clínica inicial e apresentação clínica em 30 pacientes. Dendrito 2002;8:72-76.

23. Yoshida K, Izuka T. Botulinum toxin treatment for upper airway collapse resulting from temporomandibular joint dislocation due to jaw-opening dystonia. Cranio 2006;24:217-222. 